\title{
PENGARUH KEPEMIMPINAN DAN DISIPLIN KERJA TERHADAP KINERJA BIROKRASI PELAYANAN PUBLIK DI KANTOR DESA BULO
}

\author{
Evi Erviana. N, Nirmasari \\ Prodi Ilmu Pemerintahan, Fakultas Ilmu Sosial dan Ilmu Politik \\ Universitas Muhammadiyah Sidenreng Rappang \\ eviervianan@gmail.com
}

\begin{abstract}
ABSTRAK
Tujuan dari penelitian ini adalah untuk menjawab semua pertanyaan yang ada. Survei ini diharapkan dapat memberikan pendapat kepada pemerintah (dalam hal ini aparat desa atau birokrat BULO terkait dengan kenaikan jabatan dalam struktur pemerintahan desa BULO. Kepemimpinan terutama berasal dari kata "pimpin" yang berarti "kepemimpinan”. Kata "kerja" dan "kepemimpinan" berasal dari kata benda "pemimpin", yang berarti konsesi atau kepemimpinan.Penelitian ini menggunakan tipe kualitatif dan jenis penelitian menggunakan deskriptif karena akan memberikan gambaran keadaan dari objek penelitian sesuai dengan yang ada di lapangan tentang kepemimpinan dan disiplin kerja yang mempengaruhi kinerja birokrasi pelayanan publik. Teknik pengumpulan data dalam penelitian ini adalah : Observasi, dan Study Literature Review (Library Research). Pendekatan yang digunakan pada penelitian ini yaitu dengan menggunakan pendekatan literature. Kinerja pegawai tidak dapat dilepaskan dari sumber daya yang dimiliki oleh organisasi, sumber daya yang digerakkan atau dijalankan pegawai yang berperan aktif sebagai pelaku dalam upaya mencapai tujuan organisasi tersebut. Berdasarkan perspektif tersebut hasil yang dicapai oleh seorang paratur menurut ukuran profesionalisme dalam pekerjaannya
\end{abstract}


diaplikasikan dalam prilaku, kecerdasan dana kemampuan sesuai dengan peranan, kegiatan dan tugas yang telah ditentukan.1. Hasil kerja yang dilakukan pekerja dalam melaksanakan tugas dan pekerjaan yang dibutuhkannya. Serta Integritas pegawai dalam melaksanakan tugasnya. Kemungkinan untuk tidak menyalahgunakan hak istimewa yang diberikan sangat berpengaruh pada kinerja birokrasi pelayan publik. 2. Kepemimpinan bekerja untuk orang lain (karyawan) Ini adalah kemampuan pekerja untuk membujuk mereka untuk dimobilisasi secara optimal untuk melaksanakan tugas-tugas penting. 3. Disiplin menjadi bagian yang penting dalam manajemen sumber daya manu $\neg$ sia, sebagai faktor penting dalam peningkatan produktivitas.

\section{Kata Kunci : Kepemimpinan, Birokrasi, Pelayanan publik}

\section{A. PENDAHULUAN}

Seorang pemimpin merupakan hal yang penting dalam mengatur kebutuhan masyarakat di wilayahnya. Pemimpin juga memiliki peran untuk memberikan arahan dan memberikan pengaruh yang nyata kepada bawahan atau pegawai dalam menjalankan fungsi suatu instansi. Kepemimpinan adalah kemampuan untuk mempengaruhi kelompok menuju tercapainya tujuan. Birokrasi merupakan instrumen penting dalam masyarakat modern, keberadaannya tidak dapat dielakkan sebagai konsekuensi logis dari tugas utama negara pemerintah untuk menyelenggarakan kesejahteraan umum (social welfare) seperti dalam pelayanan publik. (Mustanir et al., 2020)

Suradji dan Martono dalam Sriekaningsih (2017) (Latif, Mustanir, \& Irwan, 2019) (Mustanir, Madaling, et al., 2019) (Damis Dadda, Mustanir, Nilwana, \& Ahmad, 2019) (Mustanir \& Jaya, 2016) (Irwan, Latif, Sofyan, Mustanir, \& Fatimah, 2019), mengemukakan kepemimpinan adalah proses dalam mempengaruhi orang agar dapat memahami dan menyetujui dengan hal yang diinginkan serta berupaya untuk memfasilitasi agar dapat tercapai suatu tujuan bersama. Dalam menjalankan kepemimpinannya dan mencapai tujuan yang diinginkan, maka seorang pemimpin harus memiliki teknik kepemimpinan, karena dengan teknik kepemimpinan itulah yang akan menunjukan bahwa ia mampu untuk memimpin dan merupakan pencerminan 
jati dirinya sebagai seorang pemimpin. Syafiie (2014), teknik merupakan cara atau strategi yang dilakukan seseorang untuk mencapai tujuannya. Dalam hal ini pemimpin harus memiliki berbagai teknik dalam memengaruhi para bawahan atau masyarakatnya agar tujuan yang diharapkan segera tercapai sesuai dengan kemampuan pemimpin pemerintahan itu sendiri. Berikut ini disampaikan oleh Syafiie (2013) beberapa teknik dalam kepemimpinan pemerintahan yaitu:

a) teknik persuasif adalah strategi pemimpin pemerintahan untuk memotivasi bawahannya agar lebih rajin dalam bekerja. Ini dilakukan secara lemah lembut. Teknik ini yaitu pemimpin pemerintahan melakukan pendekatan dengan bujukan di mana untuk memotivasi bawahan atau masyarakat dipergunakan strategi pemanjaan. Dengan demikian bawahan atau masyarakat akan melaksanakan pekerjaan karena alasan baik hatinya atasan (sang pemimpin). Disimpulkan bahwa teknik persuasif ini seorang pemimpin akan memengaruhi bawahan atau masyarakatnya dengan membujuk mereka secara halus. Jika bujukan tersebut berhasil, maka mereka akan mengikuti atau bertingkah lakuseperti yang dikehendaki oleh sang pemimpin;

b) teknik komunikatif dimana teknik ini pemimpin menerapkan strategi untuk mencapai tujuan melalui komunikasi yang baik dengan masyarakat. Pemimpin pemerintahan harus memiliki media komunikasi yang baik dan benar, antara lain berbahasa dengan baik dan benar, menuliskan pesan dengan jelas, mempergunakan pengeras suara yang memadai, berada pada tempat yang resmi, ciptakan situasi di mana bawahan dan masyarakat serius. (Z. Ahmad Mustanir \& Samad, Abdul Jabbar, Monalisa Ibrahim, 2019)

Anoraga (2003: 120) mendefinisikan kepemimpinan sebagai suatu proses yang mengilhami orang untuk bekerja sekeras mungkin agar semua pegawai mendapatkan hasil yang mereka harapkan. Kepemimpinan juga merupakan dimensi utama yang menentukan hasil dari suatu organisasi. Esensi utama dari kepemimpinan adalah, upaya untuk mempengaruhi orang lebih efektif, karena kepemimpinan dapat bervariasi tergantung pada kepribadian, karakteristik tugas dan orang yang dipimpinnya. (Adam Latif, Irwan, 2019)

Sudarmanto (2009:133) mengatakan kepemimpinan adalah cara mengajak orang untuk bertindak benar dan dapat memotivasi mereka untuk mencapai tujuan bersama. Anoraga (2003:2; Mustanir \& Jaya, 2016) menggambarkan kemampuan individu untuk berkomunikasi secara langsung atau tidak 
langsung dengan kepemimpinan dalam dan tujuan untuk bersedia tunduk pada makna pemimpin. (Adam Latif, Irwan, 2019)

Kepemimpinan adalah proses memengaruhi atau memberi contoh oleh pemimpin kepada pengikutnya dalam upaya mencapai tujuan organisasi. Pemimpin adalah seseorang yang memiliki kemampuan memimpin, artinya memiliki kemampuan untuk mempengaruhi orang lain atau kelompok tanpa mengindahkan bentuk alasannya kinerja (prestasi kerja) adalah suatu hasil kerja yang dicapai seseorang dalam melaksanakan tugas-tugas yang dibebankan kepadanya yang didasarkan atas kecakapan, pengalaman dan kesungguhan serta waktu. Seorang pemimpin dapat melakukan berbagai cara dalam kegiatan mempengaruhi orang lain atau bawahan agar mau melakukan apa yang diperintahnya. Hal ini penting karena bagaimanapun seorang pemimpin mempunyai peran sebagai figur yang dapat dijadikan contoh oleh para bawahannya. Selain itu, Pemimpin juga disebut-sebut sebagai leader yang berfungsi melakukan hubungan interpersonal dengan bawahannya dengan cara memimpin, memotivasi, mengembangkan, dan mengendalikan para bawahannya supaya bekerja sesuai dengan wewenang dan tanggung jawabnya masing-masing. (M. Ahmad Mustanir et al., 2019)

Kinerja karyawan/pegawai yang baik akan mempengaruhi berhasil atau tidaknya suatu tujuan instansi serta dapat pula membantu pimpinan dalam membuat keputusan. Salah satu faktor yang perlu diperhatikan untuk meningkatkan kinerja pegawai adalah kepemimpinan yaitu bagaimana agar kepemimpinan yang diterapkan oleh pemimpin dapat menunjang kinerja pegawainya agar lebih baik. Faktor lain yang mempengaruhi kinerja pegawai selain kepemimpinan, yaitu faktor disiplin kerja. Sumber daya manusia dalam suatu instansi merupa kan faktor penting agar instansi tersebut tetap unggul dan eksis selain dari faktor keuangan dan produksi.

Semua instansi tentu memiliki standar perilaku yang harus dilakukan dalam hubungannya dengan pekerjaan, baik yang tertulis maupun yang tidak tertulis, dan menginginkan agar pegawai mematuhi sebagai upaya meningkatkan produktivitas, namun pada kenyataannya yang terjadi pegawai tak lepas dari kelemahan, diantaranya masalsah kedisiplinan. Peningkatan Disiplin menjadi bagian yang penting dalam manajemen sumber daya manusia, sebagai faktor penting dalam peningkatan produktivitas. 
Permasalahan yang kemudian muncul adalah bagaimana Usaha yang dilakukan untuk meningkatkan disiplin Kerja pegawai.

Pemimpin idealnya ada untuk memberikan perhatian serius dalam membina, mengarahkan dan menggerakan para pegawai di lingkungannya agar dapat mewujudkan stabilitas instansi peningkatan produktivitas yang beorientasi pada tujuan organisasi. (Ahmad Mustanir, Saidima, Sandi Lubis, Rais Rahmat Razak, 2019)

Permasalahan yang kemudian muncul adalah bagaimana bekerja keras untuk meningkatkan disiplin pegawai. Idealnya, pemimpin harus sungguhsungguh mendorong, membimbing, dan memobilisasi pegawai di lingkungannya untuk mencapai stabilitas organisasi, produktivitas, dan tujuan organisasi. Disiplin kerja juga penting dalam menentukan apakah tujuan organisasi dapat tercapai. Disiplin terutama mencerminkan tingkat tanggung jawab seseorang atas tugas-tugas yang diberikan kepada mereka. Tentunya pegawai dengan disiplin kerja yang baik juga akan berprestasi.

Disiplin kerja meningkatkan efisiensi kerja pegawai. Disiplin yang tidak dapat ditegakkan tidak mungkin dilaksanakan secara efektif dan efisien. Melihat permasalahan yang ada, peneliti memaparkan berbagai ekspresi permasalahan, seperti dampak kepemimpinan dan dampak disiplin kerja terhadap produktivitas. Pengaruh pelayanan publik dan kepemimpinan dan disiplin kerja, serta faktor-faktor yang mempengaruhi kepemimpinan pelayanan dan disiplin kerja Pemerintah Desa BULO. Tujuan dari penelitian ini adalah untuk menjawab semua pertanyaan yang ada. Survei ini diharapkan dapat memberikan pendapat kepada pemerintah (dalam hal ini aparat desa atau birokrat BULO terkait dengan kenaikan jabatan dalam struktur pemerintahan desa BULO. Kepemimpinan terutama berasal dari kata "pimpin" yang berarti "kepemimpinan". Kata "kerja" dan "kepemimpinan" berasal dari kata benda "pemimpin", yang berarti konsesi atau kepemimpinan.(Ahmad Mustanir, Saidima, Sandi Lubis, Rais Rahmat Razak, 2019)

G.L Freeman dan E.K. Taylor kemepimpinan merupakan kelebihan untuk menciptakan kegiatan kelompok untuk mencapai tujuan organisasi dengan efektivitas maksimal dan kerjasama dari setiap individu. Kepemimpinan tidak hanya berarti pimpinan terhadap manusianya, tetapi juga pemimpin terhadap sebuah organisasi. Seorang pemimpin tidak hanya dapat mempengaruhi anak 
buah, tetapi juga ia menjadi sumber inspirasi dan motivasi bagi bawahannya. Oleh karena itu, penafsiran dan definisi kemepimpinan semakin beragam dalam perkembanganya. Katz dan Kahn Dalam (Mustafa,2014), mengatakan bahwa kepemimpinan adalah tambahan pengaruh yang mengatasi keputusan mekanis pada pengaruh rutin organisasi, dengan kata lain kepemimpinan terjadi jika seseorang individu dapat mempengaruhi orang lain untuk mengerjakan sesuatu atas kemauanya sendiri dan bukan mengerjakan karena kewajiban atau takut dan konsekuensi dari ketidakpatuhan. (Ahmad Mustanir, Saidima, Sandi Lubis, Rais Rahmat Razak, 2019).

\section{A. TINJAUAN PUSTAKA}

\section{KEPEMIMPINAN}

Kepemimpinan adalah proses mengarahkan dan mempengaruhi aktivitas-aktivitas tugas dari orangorang dalam kelompok. Kepemimpinan berarti melibatkan orang lain, yaitu bawahan atau pegawai yang dipimpin (Sunarto, 2005).

Kepemimpinan menurut Zainuddin (2017:233) adalah kemampuan untuk mempengaruhi orang lain untuk mencapai tujuan dengan antusias, dan mampu memberikan contoh kepada pengikut-pengikutnya lewat proses komunikasi dalam upaya mencapai tujuan organisasi. Kepemimpinan merupakan proses mengarahkan, membimbing dan mempengaruhi pikiran, perasaan, tindakan dan tingkah laku orang lain untuk digerakkan kearah tujuan tertentu. Oleh karena itu kepemimpinan memainkan peranan yang amat penting, bahkan dapat dikatakan amat menentukan dalam suatu pencapaian tujuan yang telah ditetapkan sebelumnya.

Menurut Sklar (Zubaidi \& Kaelani, 2007), ada lima model demokrasi dalam pengambilan keputusan yaitu :

1) Demokrasi Liberal, dimana pemerintahan dibatasi oleh undangundang dan pemilihan umum yang bebas diselenggarakan secara rutin; 2) Demokrasi Terpimpin, di mana para pemimpin percaya bahwa semua tindakannya dipercaya oleh rakyat tetapi menolak pemilihan umum yang kompetitif karena dianggap sebagai penghalang untuk menduduki 
kekuasaan; 3) Sosial Demokrasi, demokrasi yang menjunjung tinggi keadilan dan egalitarianisme sebagai syarat untuk memperoleh kepercayaan politik; 4) Demokrasi Partisipatif, yaitu penindasan hubungan timbal balik antara penguasa dan yang diperintah; 5) Demokrasi Konstitusional, penekanan pada perlindungan khusus bagi kelompok budaya yang menekankan kerjasama yang erat antara elit yang mewakili mereka untuk masyarakat utama. (Ahmad Mustanir et al., 2018)

Kepemimpinan menurut Nurkolis (2003) adalahproses mempengaruhi atau memberi contoh oleh pemimpin kepada pengikutnya dalam upaya mencapai tujuan organisasi. Sedangkan menurut Lussier dan Achua (2010), kepemimpinan adalah proses mempengaruhi tidak hanya dari pemimpin kepada pengikut atau satu arah melainkan timbal balik atau dua arah. Karena pengikut yang baik dapat saja memunculkan kepemimpinan dengan mengikuti kepemimpinan yang ada dan pada derajat tertentu memberikan umpan balik kepada pemimpin. Gaya kepemimpinan menurut Zainuddin $(2017 ; 238)$ pada dasarnya mengandung pengertian sebagai suatu perwujudan tingkah laku dari seseorang pemimpin yang menyangkut kemampuannya dalam memimpin. (Andi Damis Dadda, Ahmad Mustanir, Andi Nilwana, 2019)

Kepemimpinan adalah bagaimana proses orang-orang menjadi pemimpin atau bagaimana dilahirkan untuk menjadi pemimpin [1] [2] [3]. [5]; [6]; [7] menyatakan bahwa indikator kepemimpinan sebagai berikut:

- Bersikap adil Dalam kegiatan organisasi, makna kebersamaan anggota adalah mutlak, karena kebersamaan merupakan representasi kesepakatan antara pimpinan dan anggota untuk mencapai tujuan organisasi.

- Memberi saran Saran umumnya disebut sebagai saran atau rekomendasi kami. Sugesti adalah pengaruh dan sebagainya, yang mampu menggerakkan kehidupan orang lain dan sugesti memiliki peran yang sangat penting dalam menjaga dan mengembangkan harga-harga penentuan nasib sendiri, partisipasi, dan kebersamaan.

- Mendukung tujuan Tujuan organisasi tidak otomatis terlaksana, harus didukung oleh pimpinan. Oleh karena itu, agar setiap organisasi dapat efektif dalam arti mampu 
mencapai tujuan, maka setiap keinginan yang ingin dicapai harus diambil agar sesuai dengan keadaan organisasi serta memungkinkan bawahan untuk bekerja sama. .

- Katalis Seorang pemimpin dikatakan berperan sebagai katalisator, jika pemimpin itu selalu meningkatkan semua sumber daya manusianya, berusaha memberikan respon yang cepat untuk bekerja secara maksimal.

- Menciptakan rasa aman Setiap pemimpin harus mempraktekkan rasa aman bagi anggotanya. Hal ini hanya dapat dilaksanakan jika ada pemimpin yang mampu menopang hal-hal positif, sikap optimis dalam menghadapi segala persoalan, sehingga menjadikan semuanya dengan cara yang benar.

- Perwakilan organisasi Setiap anggota yang bekerja di semua unit organisasi, selalu memandang pemimpinnya memiliki peran besar dalam setiap kegiatan, terutama tentang model goog. Seorang pemimpin adalah segalanya, oleh karena itu semua perkataan, tindakan, dan kebiasaannya selalu memberi kesan.

- Sumber Inspirasi Setiap pemimpin harus selalu membangkitkan semangat anggota kelompok, sehingga anggota kelompok dapat memahami dan memahami tujuan organisasi dengan antusias dan bekerja secara efektif untuk mencapai tujuan organisasi.

- Saling menghormati Setiap anggota kelompok dalam organisasi membutuhkan pengakuan dan penghargaan dari pemimpin. Oleh karena itu, sudah menjadi kewajiban seorang pemimpin untuk memberikan penghargaan atau pengakuan atas jabatan apapun kepada bawahannya. (Latif et al., 2019)

Anoraga (2003 : 120) mengartikan kepemimpinan sebagai proses memberikan inspirasi kepada semua karyawan untuk bekerja sebaikbaiknya agar dapar mencapai hasil yang diharapkan. Kepemimpinan juga merupakan dimensi utama yang sangat menentukan kinerja organisasi. Dimana esensi pokok kepemimpinan yaitu upaya mempengaruhi orang agar dapat lebih efektif, disebabkan dalam kepemimpinannya bisa berbeda 
tergantung karakter, karakteristik tugas dan siapa yang dipimpinnya. (Adam Latif, Irwan, 2019)

Kepemimpinan adalah kemampuan untuk mempengaruhi suatu kelompok menuju pencapaian tujuan. Birokrasi merupakan instrumen penting dalam masyarakat modern, keberadaannya tidak dapat dielakkan sebagai konsekuensi logis dari tugas utama pemerintah untuk menyelenggarakan kesejahteraan masyarakat (social welfare) seperti dalam pelayanan publik. Pelayanan yang berkualitas merupakan salah satu wujud dari penerapan prinsip-prinsip good governance. (Mustanir et al., 2020)

Sudarmanto (2009 : 133) mengatakan bahwa Kepemimpinan bagaimana mengajak orang bertindak dengan benar dan dapat memotivasi mereka untuk mencapai tujuan bersama. Anoraga (2003 : 2; Mustanir \& Jaya, 2016) menyatakan bahwa kepemimpinan merupakan kemampuan seseorang dalam mempengaruhi seseorang, lewat komunikasi secara langsung ataupun tidak langsung dengan tujuan menggerakkan mereka agar bersedia menuruti kehendak pemimpinnya. (Adam Latif, Irwan, 2019)

S. Pradja (26: 2014) dalam menjelaskan pemimpin dan kepemimpinan, ada beberapa hal yang perlu di perhatikan, di antaranya: pertama, kekuasaan dan kewenangan, yaitu kemampuan untuk bertindak bagi seorang pemimpin untuk menggerakkan bawahannya agar mengikuti kehendaknya dalam mencapai tujuan yang telah di tentukan sebelumnya. Kedua, kewibawaan, yaitu berbagai keunggulan yang dimiliki seorang pemimpin, sehingga membedakan dengan yang di pimpinnya, dan dengan keunggulan tersebut, orang lain patuh dan bersedia melakukan kegiatankegiatan yang di kehendakinya. Ketiga, kemampuan, yaitu keseluruhan daya, baik berupa keterampilan sosial maupun keterampilan teknis yang melebihi orang lain. (Mustanir \& Jaya, 2016)

Menurut Kartono (2010), pemimpin itu mempunyai sifat, kebiasaan, temperamen, watak dan kepribadian sendiri yang unik khas sehingga tingkah laku dan gayanya yang membedakan dirinya dari orang lain. Gaya atau style hidupnya ini pasti akan mewarnai perilaku dan tipe kepemimpinannya. Sehingga dapat memunculkan beberapa tipe 
kepemimpinan. Misalnya tipe-tipe kharismatik, paternalistik, militeristik, otokratis, laissez faire, populis, administratif dan demokratis.

Kepemimpinan itu selain untuk memberi pengarahan atau perintah tentang hal-hal yang perlu ditingkatkan mutunya, juga perlu digunakan untuk menumbuhkan motivasi intrinsik, yaitu menumbuhkan kesadaran akan perlunya setiap orang dalam perguruan tinggi itu selalu berupaya meningkatkan mutu kinerjanya masing-ma-sing secara individual maupun bersama-sama sebagai kelompok ataupun sebagai organisasi. (Mulyono, 2018)

\section{BIROKRASI}

Birokrasi adalah sistem pemerintahan yang dijalankan oleh pegawai pemerintah karena telah berpegang pada hierarki dan jenjang jabatan. Di dalam pendekatan institusional (kelembagaan), khususnya di dalam skema, tercantum 'lalu-lintas' administrasi negara dari eksekutif 'turun' ke Kebijakan Administrasi, lalu ke Administrasi dan yang terakhir ke pemilih. Artinya, setiap kebijakan negara yang diselenggarakan pihak eksekutif diterjemahkan ke dalam bentuk kebijakan administrasi negara, di mana pelaksanaan dari administrasi tersebut dilakukan oleh lembaga birokrasi. (Risnawan, 2017)

Istilah birokrasi diadopsi secara langsung dari bahasa Inggris, dari kata bureaucracy. Secara etimologis, kata itu berasal dari akar kata bureau yang berarti meja tulis, yaitu tempat pejabat biasanya bekerja, ditambah kata cracy, yang bermakna aturan (nde). Tidak heran bila dalam kamus bahasa Eropa abad ke-18 dan ke-19, istilah birokrasi diartikan sebagai kekuasaan, pengaruh, atau wewenang yang dimiliki oleh para pejabat pemerintahan (Albrow, 1996).

Dewasa ini birokrasi kerap diartikan sebagai lembaga atau institusi yang melaksanakan fungsi-fungsi, dan tanggung jawab negara. Dengan kata lain, birokrasi merupakan kamar mesin (the engine-room) nya negara (Wright, ed., 1992). Birokrasi juga sering diartikan sebagai organisasi para pejabat yang tersusun secara hirarkis dan diangkat untuk melaksanakan tujuan-tujuan publik tertentu (Halevi, 1983). 
Citra birokrasi yang ideal biasanya mengacu pada pemikiran Max Weber, sosiolog Jerman, dari para pendukungnya yang disebut sebagai Birokrasi Weberian (Weberian Bureaucracy). Birokrasi Weberian memiliki ciri utama, yaitu: (1) adanya derajat spesialisasi atau pembagian tugas yang jelas, (2) adanya struktur kewenangan hirarkhis dengan batasbatas tanggung jawab yang juga jelas, (3) hubungan antar anggota yang bersifat impersonal, (4) cara pengangkatan atau rekruitmen pagawai yang didasarkan pada kecakapan teknis, dan (5) adanya pemisahan antara urusan dinas dengan urusan pribadi yang akan menjamin pelaksanaan tugas secara efisien (Tjokrowinoto, 1995; Wright, 1992).

Mengenai fungsi birokrasi, ada tip kategori birokrasi yang melaksanakan fungsi berbeda. Pertama, birokrasi pemerintah umum, yakni institusi pemerintahan yang menjalankan tugas-tugas pemerintahan umum, termasuk tugas untuk memulihkan keamanan dan ketertiban dari tingkat pusat sampai ke daerah. Di sini birokrasi melaksanakan fungsi yang bersifat mengatur (regulative function). Kedua, birokrasi pembangunan, ialah institusi pemerintahan yang menyelenggarakan salah satu bidang khusus dalam rangka mencapai tujuan pembangunan, misalnya pendidikan, kesehatan, pertanian, industri, dan lain-lain. Dalam hal ini birokrasi menjalankan fungsi pembangunan (develop- ment function), atau fungsi adaptasi (adaptation,function). Ketiga, birokrasi pelayanan, yaitu unit-unit institusi yang berhubungan secara langsung dengan masyarakat, dengan memberikan jasa atau pelayanan. Termasuk dalam kategori birokrasi pelayanan, ialah sekolah-sekolah (dari tingkat SD hingga SMU), rumah sakit, kantor koperasi, bank rakyat, jawatan sosial, transmigrasi, dan lain sebagainya. Fungsi utama birokrasi kategori ketiga ini adalah fungsi pelayanan (service Action) (Abdullah dalam Millah Din Syamsuddin, peny., 1991) (Suwarno, 2008).

\section{PELAYANAN PUBLIK}

Dalam kontek good governance, pelayanan publik merupakan gerbang utama reformasi birokrasi pemerintah, karena di dalam pelayanan publik merupakan ruang dimana birokrasi pemerintahan berinteraksi secara langsung dengan masyarakat. Di era New Public Service inilah pelayanan publik harus lebih responsif karena akan langsung terpantau secara transparan oleh masyarakat. 
Pelayanan merupakan salah satu ujung tombak dari upaya pemuasan pelanggan dan sudah merupakan keharusan yang wajib dioptimalkan baik oleh individu maupun organisasi, karena dari bentuk pelayanan yang diberikan tercermin kualitas individu atau organisasi yang memberikan pelayanan publik yang baik.

Menurut Hardiyansyah, (2018) mendefinisikan bahwa“ pelayanan dapat diartikan sebagai aktivitas yang diberikan untuk membantu, menyiapkan, dan mengurus baik itu berupa barang atau jasa dari satu pihak ke pihak lain". Pelayanan pada hakikatnya adalah serangkaian kegiatan, karena itu pelayanan berlangsung secara rutin dan berkesinambungan, meliputi seluruh kehidupan organisasi dalam masyarakat. (HIDAYAH, 2020)

Adalah tanggung jawab semua pegawai untuk melayani masyarakat dengan baik. Oleh karena itu, semua pegawai belajar bagaimana melayani dan meningkatkan keterampilan mereka dalam melayani masyarakat. Teknologi layanan melibatkan perolehan pengetahuan tentang layanan yang disediakan. Hal ini untuk menunjukkan kepada masyarakat bahwa pegawai adalah ahli di bidang manajemen pelayanan publik. Para profesional di bidang pelayanan publik perlu memahami kebutuhan masyarakat dan mengetahui cara memenuhinya agar dapat memenuhinya. (Jamal et al., 2020)

\section{B. METODOLOGI}

Penelitian ini menggunakan tipe kualitatif dan jenis penelitian menggunakan deskriptif karena akan memberikan gambaran keadaan dari objek penelitian sesuai dengan yang ada di lapangan tentang kepemimpinan dan disiplin kerja yang mempengaruhi kinerja birokrasi pelayanan publik. Teknik pengumpulan data dalam penelitian ini adalah : Observasi, dan Study Literature Review (Library Research). Pendekatan yang digunakan pada penelitian ini yaitu dengan menggunakan pendekatan literature. Dalam melakukan pengumpulan data, peneliti mengumpulkan data dan sumber informasi yang berhubungan dengan Pengaruh kepemimpinan dan disiplin kerja terhadap kinerja birokrasi pelayanan publik melalui data-data 
pendukung yang bersumber dari jurnal penelitian yang relevan, artikel, ulasan, rangkuman, dan pemikiran penulis tentang beberapa sumber pustaka.

\section{HASIL DAN PEMBAHASAN}

Konsep kinerja pada dasarnya dapat dilihat dari dua sisi, yaitu kinerja pegawai(perindividu) dan kinerja organisasi. Kinerja adalah gambaran mengenai tingkat pencapaian pelaksanaan tugas dalam suatu organisasi, dalam upaya mewujudkan sasaran, tujuan, misi, dan visi organisasi tersebut (Bastian,2001:329). Pegawai adalah orang yang melakukan pekerjaan dengan mendapatkan imbalan jasa berupa gaji dan tunjangan dari pemerintah. Unsur manusia sebagai pegawai maka tujuan badan (wadah yang telah ditentukan) kemungkinan besar tecapai sebagaiman yang diharapkan. Pegawai inilah yang mengerjakan segala pekerjaan atau kegiatan penyelenggaraan pemerintahan. Berdasarkan penjelasan diatas, maka pengertian kinerja pegawai adalah hasil kerja seseorang dalam suatu organisasi Gambaran mengenai tingkat pencapaian pelaksanaan tugas yang dilakukan oleh seluruh pegawai yang ada disuatu organisasi atau instansi pemerintah. Meningkatkan kinerja dalam sebuah organisasi atau instansi pemerintah merupakan tujuan yang ingin dicapai oleh organisasi dan instansi pemerintah dalam memaksimalkan suatu kegiatan. Kinerja organisasi adalah totalitas hasil kerja yang dicapai suatu organisasi. Kinerja pegawai dan kinerja organisasi memiliki keterkaitan yang sangat erat, tercapainya tujuan organisasi.

Kinerja pegawai tidak dapat dilepaskan dari sumber daya yang dimiliki oleh organisasi, sumber daya yang digerakkan atau dijalankan pegawai yang berperan aktif sebagai pelaku dalam upaya mencapai tujuan organisasi tersebut. Berdasarkan perspektif tersebut hasil yang dicapai oleh seorang paratur menurut ukuran profesionalisme dalam pekerjaannya diaplikasikan dalam prilaku, kecerdasan dana kemampuan sesuai dengan peranan, kegiatan dan tugas yang telah ditentukan. Aparatur kantor desa BULO dalam memberdayakan dan memaksimalkan suatu kinerja dalam memberikan pelayanan Publik kepada masyarakat, diperlukan pemahaman dalam melaksanakan tugasnya, sehingga menghasilkan apa yang menjadi tujuan yang telah ditatapkan. Organisasi pemerintahan dalam hal ini Kantor Desa BULO menggunakan alat untuk mengukur suatu kinerja birokrasi publik, indikator yang digunakan menurut Baban Sobandi dan para ahli lainnya dalam bukunya yang berjudul Desentralisasi dan Tuntutan Penataan 
Kelembagaan daerah sebagai berikut: (1) Keluaran; (2) hasil; (3) Kaitan dengan usaha deengan pencapaian target (Sobandi, 2006 : 179). Pertama, keluaran adalah sesuatu yang diharapkan lansung dicapai dari suatu kegiatan yang berupa fisiki atau non fisik. Suatu kegiatan yang berupa fisik maupun non fisik yang diharapkan oleh suatu organisasi atau instansi dapat dirasakan lansung oleh masyarakat. (Z. Ahmad Mustanir \& Samad, Abdul Jabbar, Monalisa Ibrahim, 2019)

Ukuran keluaran disini dapat dilihat dari dua sub indikator yaitu kualitas sumber daya aparatur yang ada dikantor Desa BULO, kuantitas merupakan suatu hasil pelayanan yang dapat memenuhi uji kualitas. Kedua, hasil adalah mengukur pencapaian atau hasil yang terjadi karena pemberian layanan. segala sesuatu yang mencerminkan berfungsinya keluaran kegiatan pada jangka menengah (efek lansung). Maka segala kegiatan yang dilakukan atau dilaksanakan pada jangka menengah oleh Kantor Desa BULO harus dapat memberikan efek langsung kepada kegiatan tersebut. Ketiga, kaitan usaha dengan pencapaian adalah usaha yang dilakukan oleh kantor Desa BULO dalam memberikan pelayanan publik bagi masyarakat bisa tercapai sesuai dengan tujuan pelayanan public.

Kinerja aparatur dalam memberdayakan standar operasipnal prosedur (SOP) harus dapat ditentukan dengan pencapaian target selama periode waktu yang dicapai organisasi. Berhasil tidaknya tujuan dan cita- cita dalam organiasasi pemerintah tergantung bagaimana proses kinerja itu dilaksanakan. Kinerja tidak lepas dari faktor-faktor yang mempengaruhi. Berikut faktorfaktor yang mempengaruhi kinerja sebagaimana yang telah dikemukakan oleh Keith Davis dalam buku Anwar Prabu Mangkunegara, yaitu: (1) Faktor kemampuan. Secara psikologis , kemampuan ability yang terdiri dari kemampuan potensi; (2) IQ dan kemampuan reality, Knowledge dan Skill. Artinya pimpinan dan karyawan yang memiliki IQ superior, gifted dan genius dengan Pendidikan yang memadahi untuk jabatan dan terampil dalam menjalankan pekerjaan sehari-hari maka akan mudah menjalankan kinerja maksimal; (2) Faktor motivasi. Motivasi diartiakan sebagai suatu sikap attitude pimpinan dan karyawan terhadap situasi kerja dilingkungan kerja organisasinya. Mereka yang bersikap positif terhadap situasi kerjanya akan menunjukkan motivasi kerja tinggi dan sebaliknya jika mereka berpikir negative terhadap situasi kerjanya akan menunjukkan motivasi kerja yang rendah. Situasi yang dimaksud meliputi hubungan kerja, fasilitas kerja, iklim 
kerja, kebijakan pimpinan, pola kepemimpinan kerja dan kondisi kerja (Mangkunegara, 2000:13).

Kinerja dipengaruhi oleh beberapa faktor pendukung dan penghambat berjalannya suatu pencapaian kinerja yang maksimal, faktor tersebut meliputi faktor yang berasal dari intern maupun ektern. Menilai suatu kinerja apakah sudah berjalan dengan yang direncanakan perlu diadakan suatu evaluasi kinerja sebagaimana yang dikemukakan oleh Andrew E. Sikula dalam buku Anwar Prabu Mangkunegara. "Evaluasi kinerja atatu penilaian merupakan suatu evaluasi yang sistematis dari pekerjaan pegawai dan potensi yang dapat dikembangkan. Penilaian dalam proses penafsiran atau penentuan niali, kualitas atau status dari beberapa objek orang ataupun suatu barang”. (Mangkunegara 2006: 69)

Dalam mengevaluasi kinerja, partisipasi masyarakat dalam hal ini diperlukan. Lingkup partisipasi dengan bertolak pada urutan proses perencanaan pembangunan, maka secara rinci jenis partisipasi dalam pembangunan sebagai berikut:

1. Partisipasi dalam pengambilan keputusan

2. Partisipasi dalam pelaksanaan kegiatan

3. Partisipasi dalam pemantauan dan evaluasi pembangunan

4. Partisipasi dalam pemanfaatan hasil-hasil pembangunan

(Mustanir \& Abadi, 2017)

Aparatur sebagai pelayan masyarakat, harus memberikan pelayanan terbaik untuk mencapai suatu kinerja. Kenyataannya untuk mencapai kinerja yang diinginkan tidaklah mudah, banyak hambatan-hambatan yang harus dilewati. Menurut Keith Davis dalam A.A. Anwar Prabu Mangkunegara terdapat beberapa faktor yang mempengaruhi pencapain kinerja, faktor tersebut berasal dari factor kemampuan dan motivasi aparatur. Berdasarkan hal tersebut maka akan dijelaskan sebagai berikut: "Faktor yang mempengaruhi pencapaian kinerja adalah factor kemampuan (ability) dan faktor motivasi (motivation), yang dirumuskan sebagai berikut: "Human Performance $=$ Ability + Motivation, Motivation $=$ Atitude + Situation, Ability = Knowledge + Skill" (Mangkunegara, 2005:13) (Ahmad Mustanir, Saidima, Sandi Lubis, Rais Rahmat Razak, 2019)

Untuk mencapai kinerja, pegawai harus fungsional dan termotivasi untuk bekerja. Kekuatan pegawai dapat berupa kecerdasan atau bakat. Motivasi pegawai terlihat melalui sikap dan kondisi kerja yang kondusif 
karena terkait dengan penyelesaian pekerjaan atau kinerja pegawai di kantor Desa BULO melayani masyarakat.

Selanjutnya B Sastrohardiwiryo (2002:111) menjelaskan bahwa faktor kinerja secara umum adalah: (1) Prestasi kerja adalah hasil kerja yang dilakukan pekerja dalam melaksanakan tugas dan pekerjaan yang dibutuhkannya. Hal ini ditugaskan. (2) Rasa tanggung jawab yaitu kemampuan karyawan untuk menyelesaikan tugas dan kegiatan yang diberikan tepat waktu. (3) Ketulusan, yaitu integritas pegawai dalam melaksanakan tugasnya. Kemungkinan untuk tidak menyalahgunakan hak istimewa yang diberikan. ( ) Kesediaan tenaga kerja untuk bekerja dengan orang lain untuk melakukan tugas yang diberikan dan bekerja untuk efektivitas dan efisiensi maksimum (5) Kepemimpinan bekerja untuk orang lain (karyawan) Ini adalah kemampuan pekerja untuk membujuk mereka untuk dimobilisasi secara optimal untuk melaksanakan tugas-tugas penting. Sesuai dengan hak tersebut, sebaiknya membuat evaluasi pekerjaan yang berkaitan erat dengan kriteria kinerja dan menggunakannya sebagai acuan untuk kriteria perbandingan (criteria comparison).

Kriteria tersebut dapat dijadikan sebagai tolak ukur untuk mengukur akuntabilitas atas tindakan yang dilakukan. Nilai ini mengacu pada jenis perilaku yang diyakini manajemen sebagai kepentingan terbaik perusahaan. Nilai Bisnis Inti mewakili keyakinan pada apa yang dianggap penting oleh manajemen untuk berfungsinya perusahaan dan perilaku orang. Tujuannya adalah untuk memastikan bahwa keyakinan ini juga dimiliki oleh karyawan. Strategi manajemen budaya perlu menganalisis perilaku yang sesuai dan mengintegrasikannya ke dalam proses seperti manajemen kinerja untuk mempercepat pengembangan perilaku ini.

\section{KESIMPULAN}

Berdasarkan hasil analisis pengaruh kepemimpinan dan disiplin kerja terhadap kinerja birokrasi pelayanan publik pada KantorDesa BULO, maka dapat kemukakan beberapa kesimpulan, sebagai berikut: 
1. Hasil kerja yang dilakukan pekerja dalam melaksanakan tugas dan pekerjaan yang dibutuhkannya. Rasa tanggung jawab yaitu kemampuan karyawan untuk menyelesaikan tugas dan kegiatan yang diberikan tepat waktu. Serta Integritas pegawai dalam melaksanakan tugasnya. Kemungkinan untuk tidak menyalahgunakan hak istimewa yang diberikan sangat berpengaruh pada kinerja birokrasi pelayan publik.

2. Kepemimpinan bekerja untuk orang lain (karyawan) Ini adalah kemampuan pekerja untuk membujuk mereka untuk dimobilisasi secara optimal untuk melaksanakan tugas-tugas penting.

3. Disiplin menjadi bagian yang penting dalam manajemen sumber daya manusia, sebagai faktor penting dalam peningkatan produktivitas. 


\section{DAFTAR PUSTAKA}

Adam Latif, Irwan, A. M. (2019). Analisis Kepemimpinan Terhadap Optimalisasi Masyarakat Pada Perencanaan Pembangunan Di Enrekang. 5(2), 1-20. https://doi.org/10.20956/xxxxxx

Ahmad Mustanir, Saidima, Sandi Lubis, Rais Rahmat Razak, A. M. (2019). Pengaruh Kepemimpinan dan Disiplin Kerja Terhadap Kinerja Birokrasi Pelayanan Publik pada Kantor Kecamatan Buntu Batu Kabupaten Enrekang. 525-541.

Ahmad Mustanir, M., Andi Uceng, M.Nurzin R. Kasau, B., \& Andriani, D. (2019). KARAKTERISTIK KEPEMIMPINAN LURAH TERHADAP PARTISIPASI MASYARAKAT DALAM MUSYAWARAH PERENCANAAN PEMBANGUNAN DI KELURAHAN DUAMPANUA KECAMATAN BARANTI KABUPATEN SIDENRENG RAPPANG. 2(2), 145-172.

Ahmad Mustanir, Nur Justira, Kamaruddin Sellang, \& Andi Ilham Muchtar. (2018). Democratic Model On Decision-Making At Deliberations Of Development Planning. International Conference on Government Leadership and Social Science (ICOGLASS). Demanding Governance Accountability and Promoting Democratic Leadership for Public Welfare Achievement, April, 110 - 115. https://www.researchgate.net/publication/330090538_Democratic_Model_On_D ecision-Making_At_Deliberations_Of_Development_Planning

Ahmad Mustanir, Z., \& Samad, Abdul Jabbar, Monalisa Ibrahim, J. (2019). KEPEMIMPINAN LURAH TERHADAP PEMBERDAYAAN MASYARAKAT DI KELURAHAN LAUTANG BENTENG KABUPATEN SIDENRENG RAPPANG. Journal of Social Politics and Governance, 1(2), 2039.

Andi Damis Dadda, Ahmad Mustanir, Andi Nilwana, J. (2019). Pengaruh Kepemimpinan Lurah Perempuan Terhadap Stabilitas Kamtibmas Di Kelurahan Rappang Kabupaten Sidenreng Rappang. Konferensi Nasional Ke-8 Asosiasi Program Pascasarjana Perguruan Tinggi Muhammadiyah Aisyiyah (APPPTMA), 1-6.

HIDAYAH, D. D. (2020). KUALITAS PELAYANAN PUBLIK( Studi Pelayanan Administrasi Kependudukan Di Kecamatan Cipatujah KabupatenTasikmalaya ). 7(1), 28-34.

Jamal, Y., Mustanir, A., \& Latif, A. (2020). Penerapan Prinsip Good Governance Terhadap Aparatur Desa Dalam Pelayanan Publik Di Desa Ciro-Ciroe Kecamatan Watang Pulu Kabupaten Sidenreng Rappang. PRAJA: Jurnal Ilmiah Pemerintahan, 8(3), 207-212. https://doi.org/10.51817/prj.v8i3.298 
Latif, A., Irwan, Mustanir, A., Ahmad, J., \& Sakkir, G. (2019). Village Government Leadership Towards Optimizing Society Participation in Development Planning. 367(ICDeSA), 12-16. https://doi.org/10.2991/icdesa-19.2019.3

Mulyono, H. (2018). KEPEMIMPINAN (LEADERSHIP) BERBASIS KARAKTER DALAM PENINGKATAN KUALITAS PENGELOLAAN PERGURUAN TINGGI. 3(1), 290-297.

Mustanir, A., \& Abadi, P. (2017). Partisipasi Masyarakat Dalam Musyawarah Rencana Pembangunan Di Kelurahan Kanyuara Kecamatan Watang Sidenreng Kabupaten Sidenreng Rappang. Jurnal Politik Profetik, 5(2), 247-261. http://journal.uinalauddin.ac.id/index.php/jpp/article/viewFile/4347/3986\%0Ahttp://journal.uinalauddin.ac.id/index.php/jpp/issue/view/636

Mustanir, A., \& Jaya, I. (2016). Pengaruh Kepemimpinan Dan Budaya Politik Terhadap Perilaku Pemilih Towani Tolotang Di Kecamatan Maritengngae Kabupaten Sidenreng Rappang. Jurnal Politik Profetik, 4(1), 84-97. http://journal.uinalauddin.ac.id/index.php/jpp/article/view/2741\#\%0Ahttp://journal.uinalauddin.ac.id/index.php/jpp/issue/view/430

Mustanir, A., Jermsittiparsert, K., Ali, A., Hermansyah, S., \& Sakinah, S. (2020). Village Head Leadership and Bureaucratic Model Towards Good Governance in Sidenreng Rappang. https://doi.org/10.4108/eai.21-10-2019.2291532

Risnawan, W. (2017). Fungsi Birokrasi dalam Efektivitas Pelayanan Publik. 156166.

Suwarno. (2008). Birokrasi Indonesia : Perspektif Teoritik. XXXI(69), 254-261. 